\title{
Effect of Graphene-Graphene Oxide Modified Anode on the Performance of Microbial Fuel Cell
}

\author{
Na Yang, Yueping Ren *, Xiufen Li * and Xinhua Wang \\ Jiangsu Key Laboratory of Anaerobic Biotechnology, Jiangsu Cooperative Innovation Center of Technology and \\ Material of Water Treatment, School of Environmental and Civil Engineering, Jiangnan University, Wuxi 214122, \\ Jiangsu, China; yangna191991@126.com (N.Y.); xhwang@jiangnan.edu.cn (X.W.) \\ * Correspondence: ypren@jiangnan.edu.cn (Y.R.); xfli@jiangnan.edu.cn (X.L.); \\ Tel.: +86-510-8532-6516 (Y.R. \& X.L.)
}

Academic Editor: Lital Alfonta

Received: 15 May 2016; Accepted: 1 September 2016; Published: 15 September 2016

\begin{abstract}
The inferior hydrophilicity of graphene is an adverse factor to the performance of the graphene modified anodes ( $G$ anodes) in microbial fuel cells (MFCs). In this paper, different amounts of hydrophilic graphene oxide (GO) were doped into the modification layers to elevate the hydrophilicity of the $\mathrm{G}$ anodes so as to further improve their performance. Increasing the GO doped ratio from $0.15 \mathrm{mg} \cdot \mathrm{mg}^{-1}$ to $0.2 \mathrm{mg} \cdot \mathrm{mg}^{-1}$ and $0.25 \mathrm{mg} \cdot \mathrm{mg}^{-1}$, the static water contact angle $\left(\theta_{\mathrm{c}}\right)$ of the G-GO anodes decreased from $74.2 \pm 0.52^{\circ}$ to $64.6 \pm 2.75^{\circ}$ and $41.7 \pm 3.69^{\circ}$, respectively. The G-GO 0.2 anode with GO doped ratio of $0.2 \mathrm{mg} \cdot \mathrm{mg}^{-1}$ exhibited the optimal performance and the maximum power density $\left(P_{\max }\right)$ of the corresponding MFC was $1100.18 \mathrm{~mW} \cdot \mathrm{m}^{-2}, 1.51$ times higher than that of the MFC with the $G$ anode.
\end{abstract}

Keywords: graphene; graphene oxide (GO); microbial fuel cell (MFC); modified anode; hydrophilicity

\section{Introduction}

Microbial fuel cell (MFC) is an emerging technology that converts chemical energy of organic pollutants directly into electricity with electro-active microorganisms as catalysts [1,2]. However, the low power density of MFCs has long been one of the critical problems that limited their practical applications in microbial sensors, biological remediation and wastewater treatment [3,4]. In MFCs, anodes are the habitats of the microorganisms and their hydrophilicity is a significant factor that influences the attachment of the microorganisms and the formation of highly active biofilms $[5,6]$. Guo and coworkers [7] reported that glassy carbon (GC) anodes modified by hydrophilic functional groups $\left(-\mathrm{N}^{+}\left(\mathrm{CH}_{3}\right)_{3},-\mathrm{SO}_{3}{ }^{-}\right.$or $\left.-\mathrm{OH}\right)$ exhibited faster initial bacterial adhesion and higher anode biomass than the hydrophobic GC anode (modified by $-\mathrm{CH}_{3}$ ). Moreover, the current densities of the hydrophilic $-\mathrm{N}^{+}\left(\mathrm{CH}_{3}\right)_{3},-\mathrm{SO}_{3}{ }^{-}$or $-\mathrm{OH}$ functionalized GC anodes are more than 2.5 times higher than that of the $-\mathrm{CH}_{3}$ functionalized GC anode. In the last couple of years, the positive effect of the graphene modified anodes (G anodes) on promoting the electricity generation performance of MFCs has been verified [8,9]. However, the inferior hydrophilicity of graphene is an adverse factor to the performance of the $\mathrm{G}$ anodes. Thus, ameliorating the hydrophilicity of the $\mathrm{G}$ anodes should be an effect strategy to further improve their performance. Graphene oxide (GO) is single- or few layer graphite oxide which is often used as the precursor of graphene in the chemical synthesis route [10,11]. In GO molecular structure, the contiguous aromatic lattice is interrupted by epoxides, hydroxyls, ketone carbonyls, and carboxylic groups [12]. Within this, the hydroxyls and carboxylic groups endowed GO excellent hydrophilic property and it has been widely used in the hydrophilic modification of filtering membranes $[13,14]$ and fabrics [15]. In this paper, different amounts of GO were doped into the graphene modified layers to elevate the hydrophilicity of the anode surfaces so as to further enhance the performance of the $G$ 
anodes. The influence of the hydrophilicity variation of the G-GO anodes on the electrogenesis and the organics efficacious utilization in the corresponding MFCs has been investigated in detail.

\section{Experimental}

\subsection{Chemicals and Materials}

Graphene and graphene oxide (GO) was purchased from Suzhou Graphene Nano Tech Co. Ltd. (Suzhou, China). Carbon cloth and polytetrafluoroethylene (PTFE) solution (60 wt \%) were purchased from Hesen Electric Co. Ltd., (Shanghai, China). Activated carbon (AC), carbon black (CB), and stainless steel mesh (SSM) were purchased from Xinsen Carbon Co. Ltd. (Shaowu, China), Jinqiushi Chemical Co. Ltd. (Tianjin, China) and Anping Ruishen Mesh Co. Ltd. (Anping, China), respectively.

\subsection{Electrode Fabrication}

Graphene powder of $10 \mathrm{mg}$, certain amount of GO powder $(1.5 \mathrm{mg}, 2.0 \mathrm{mg}$ and $2.5 \mathrm{mg}), 1 \mathrm{~mL}$ PTFE emulsion $(60 \%)$ and $1 \mathrm{~mL}$ ultrapure water were evenly mixed into paste. Then the pastes were coated on round carbon cloths $(3 \mathrm{~cm}$ in diameter) and dried at room temperature, respectively. These anodes were named as $\mathrm{G}, \mathrm{G}-\mathrm{GO}_{0.15}, \mathrm{G}-\mathrm{GO}_{0.2}$ and $\mathrm{G}-\mathrm{GO}_{0.25}$, according to the doped ratios of the $\mathrm{GO}\left(\mathrm{GO} / \mathrm{G}, \mathrm{mg} \cdot \mathrm{mg}^{-1}\right)$ in the modified layer $\left(0.15 \mathrm{mg} \cdot \mathrm{mg}^{-1}, 0.2 \mathrm{mg} \cdot \mathrm{mg}^{-1}\right.$ and $\left.0.25 \mathrm{mg} \cdot \mathrm{mg}^{-1}\right)$. The AC air-cathodes were made by the previously reported rolling-press method [16].

\subsection{MFC Construction and Operation}

Single-chamber cubic-shaped MFC reactors containing a cylindrical anode chamber $(28 \mathrm{~mL})$ which was $4 \mathrm{~cm}$ long and $3 \mathrm{~cm}$ in diameter were used in this work [17]. The anode and the cathode were placed vertically in the two ends of the cylindrical chamber. All the MFC reactors were inoculated with anaerobic sludge (Taihu Newtown Wastewater Treatment Plant, Wuxi, China), operated at $30{ }^{\circ} \mathrm{C}$ and fed the medium containing sodium acetate $\left(1 \mathrm{~g} \cdot \mathrm{L}^{-1}\right)$, phosphate buffer solution $\left(2.77 \mathrm{~g} \cdot \mathrm{L}^{-1}\right.$ $\mathrm{Na}_{2} \mathrm{HPO}_{4} \cdot 2 \mathrm{H}_{2} \mathrm{O}, 11.53 \mathrm{~g} \cdot \mathrm{L}^{-1} \mathrm{NaH}_{2} \mathrm{PO}_{4} \cdot 12 \mathrm{H}_{2} \mathrm{O}, 0.31 \mathrm{~g} \cdot \mathrm{L}^{-1} \mathrm{NH}_{4} \mathrm{Cl}, 0.13 \mathrm{~g} \cdot \mathrm{L}^{-1} \mathrm{KCl}$ ), trace mineral $\left(12.5 \mathrm{~mL} \cdot \mathrm{L}^{-1}\right)$ and vitamin $\left(5 \mathrm{~mL} \cdot \mathrm{L}^{-1}\right)$ solution [18].

\subsection{Measurement and Analysis}

The output voltage $(U)$ across the external resistor $(1000 \Omega)$ was recorded at 30 min intervals by a data acquisition system (34972A, Agilent Technology Co. Ltd., Santa Clara, CA, USA) connected to a computer. After the electrogenesis of the MFC reached the steady state, a resistance box (ZX79JD, Xian Instruments Company, Xi'an, China) was connected to the MFC and the external resistor was varied from $68 \Omega$ to 33,000 $\Omega$ with a time interval of $30 \mathrm{~min}$. The voltages and the electrode potentials at different external resistors were tested by a digital multimeter (UT70B, Uni-Trend Technology Ltd., Dongguan, China). The corresponding current density and output power density were calculated according to the Ohm's law. The static water contact angles of the anode surfaces were measured by the automatic video optical contact angle measuring system (OCA 40, Dataphysics, Filderstadt, Germany). Chemical oxygen demand (COD) was tested according to the Standard Methods (APHA, 1998) for each cycle and conducted in triplicates for all samples [5]. The coulombic efficiency (CE) was calculated by the previously reported method [19]. Electrochemical characterizations were performed in the three-electrode system using the electrochemical workstation (CHI660D, Chenhua Instruments Co. Ltd., Shanghai, China). The anode, Pt wire electrode and the saturated calomel electrode (SCE) were used as working electrode, counter electrode and reference electrode, respectively. The cyclic voltammograms (CVs) were tested at the scan rate of $5 \mathrm{mV} \cdot \mathrm{s}^{-1}$ from $-0.5 \mathrm{~V}$ to $0.5 \mathrm{~V}$ in the $50 \mathrm{mM}$ PBS. The electrochemical impedance spectra (EIS) were measured over the frequency range of $0.01 \sim 100,000 \mathrm{~Hz}$ at open circuit potential and the amplitude was $5 \mathrm{mV}$ [20]. The biomass of anodes was determined by phospholipid analysis according to the previously reported method [21]. The absorbance at $610 \mathrm{~nm}$ was then read using a spectrophotometer (UV-1800, Shimadzu, Japan) 
and the biomass concentration was expressed as the mass of phosphorus per square centimeter of anode $\left(\mu \mathrm{g} \cdot \mathrm{cm}^{-2}\right)$.

\section{Results and Discussion}

\subsection{Hydrophilicity of G-GO Anodes}

The static water contact angles $\left(\theta_{\mathrm{c}}\right)$ of the $\mathrm{G}$ and G-GO anodes were tested to evaluate their hydrophilicity. As illustrated in Figure 1 , the $\theta_{c}$ of the $G$ anode was $82.1 \pm 1.88^{\circ}$ and with the increase of the GO doped ratio from $0.15 \mathrm{mg} \cdot \mathrm{mg}^{-1}$ to $0.2 \mathrm{mg} \cdot \mathrm{mg}^{-1}$ and $0.25 \mathrm{mg} \cdot \mathrm{mg}^{-1}$, the $\theta_{\mathrm{c}}$ of the G-GO anodes gradually decreased from $74.2 \pm 0.52^{\circ}$ to $64.6 \pm 2.75^{\circ}$ and $41.7 \pm 3.69^{\circ}$ indicating the hydrophilicity improvement of the anode surfaces [22].

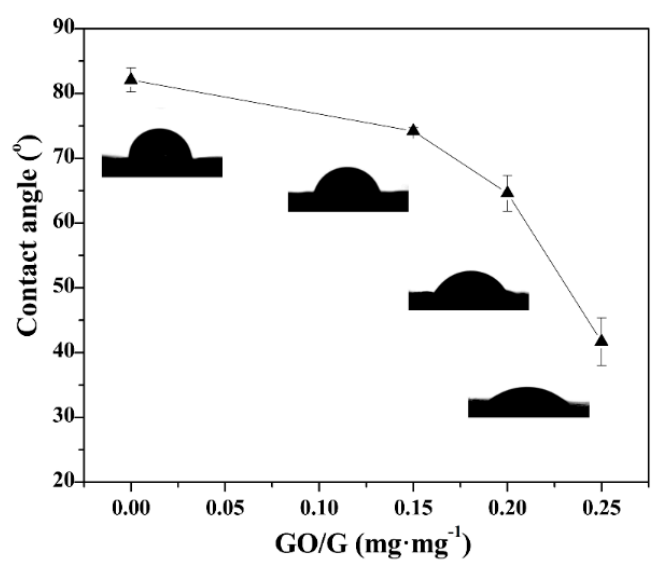

Figure 1. The static water contact angles $\left(\theta_{c}\right)$ of the $\mathrm{G}$ and $\mathrm{G}-\mathrm{GO}$ anodes.

\subsection{Performance of G-GO Anodes}

To investigate the performance of the G-GO anodes, four MFC reactors were run in parallel. As shown in Figure 2, all four MFCs reached steady electrogenesis state after $\sim 119 \mathrm{~h}$, and the average $U$ of the MFCs at stable status with the $\mathrm{G}, \mathrm{G}-\mathrm{GO}_{0.15}, \mathrm{G}-\mathrm{GO}_{0.2}$ and $\mathrm{G}-\mathrm{GO}_{0.25}$ anodes were $0.45 \mathrm{~V}, 0.47 \mathrm{~V}$, $0.52 \mathrm{~V}$ and $0.42 \mathrm{~V}$, respectively. It was worth noting that the MFC with the G-GO $\mathrm{G}_{0.2}$ anode rather than the $\mathrm{G}_{-} \mathrm{GO}_{0.25}$ anode exhibited the optimal $U$. This was probably because excessive $\mathrm{GO}$ increased the hydrophilicity, but, at the same time, decreased the conductivity or the electrochemical activity of the modified layer.

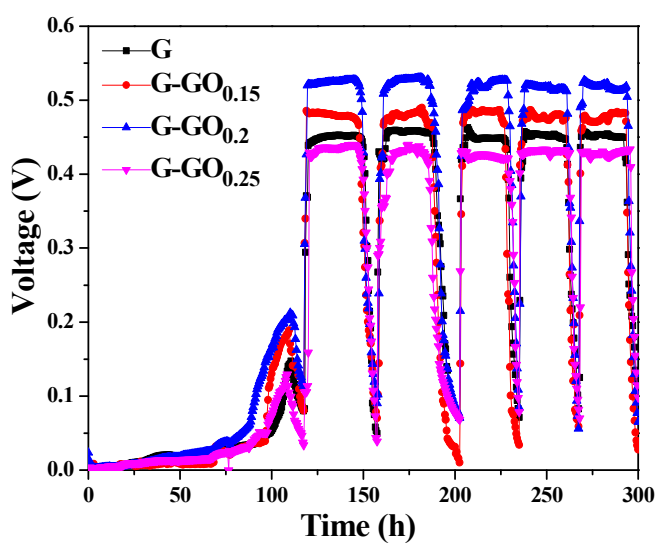

Figure 2. Output voltages of the microbial fuel cells (MFCs) with graphene (G) and G-graphene oxide (GO) anodes. 
The output power density and polarization curves were illustrated in Figure 3. As can be seen from Figure 3a, the maximum power density $\left(P_{\max }\right)$ of the MFCs with the $\mathrm{G}$ anode was $730.72 \mathrm{~mW} \cdot \mathrm{m}^{-2}$. However, the $P_{\max }$ of the MFC with the G-GO ${ }_{0.15}, \mathrm{G}_{-}-\mathrm{GO}_{0.2}$ and $\mathrm{G}-\mathrm{GO}_{0.25}$ anodes were $951.08 \mathrm{~mW} \cdot \mathrm{m}^{-2}$, $1100.18 \mathrm{~mW} \cdot \mathrm{m}^{-2}$ and $622.18 \mathrm{~mW} \cdot \mathrm{m}^{-2}$, respectively. The MFC with the $\mathrm{G}-\mathrm{GO}_{0.2}$ anode exhibited the highest $P_{\max }$, which was 1.51 times higher than that of the MFC with the G anode. However, the $P_{\max }$ of the G-GO $\mathrm{GO}_{0.25}$ anode MFC decreased by $14.85 \%$ compared with the $\mathrm{G}$ anode. Thus it can be seen that a moderate amount of GO doping in the modified layer was the crux for further enhancing the performance of the $\mathrm{G}$ anodes. Figure $3 \mathrm{~b}$ showed the electrode potentials of the different MFCs with SCE as the reference electrodes. The cathode potentials were almost the same while the potentials of anodes were different, indicating that the differences in power densities were mainly caused by the anodes [23].
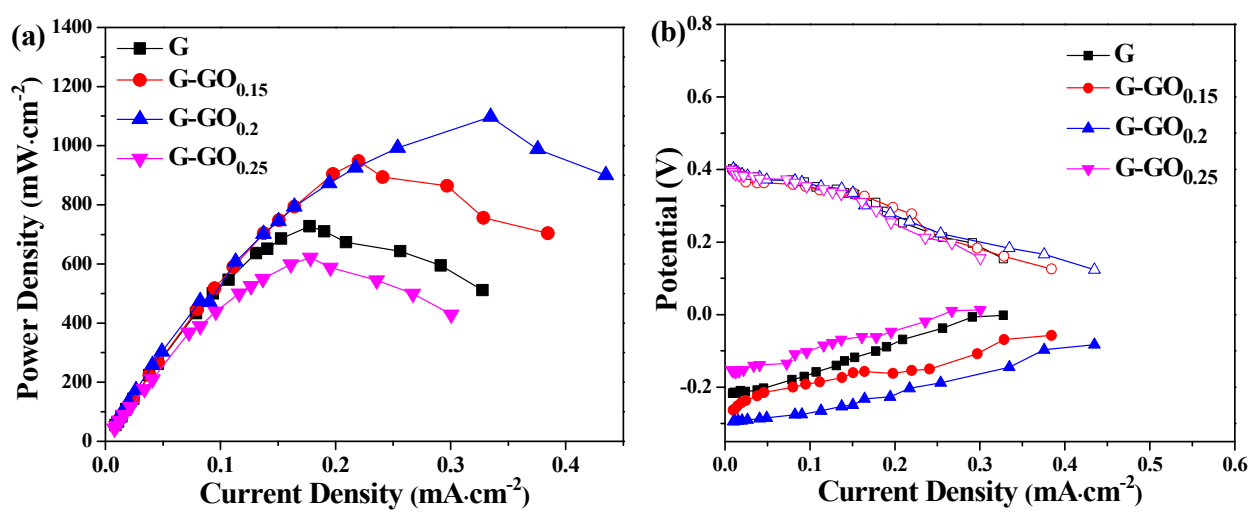

Figure 3. (a) Power density curves and (b) electrode potentials of the MFCs with G and G-GO anodes.

\subsection{Substrate Utilization and Coulombic Recovery}

The COD removal efficiency and the coulomb efficiency (CE) of the MFCs with G and G-GO anodes were illustrated in Figure 4. COD removal efficiencies of the G, G-GO $\mathrm{GO}_{0.15}, \mathrm{G}-\mathrm{GO}_{0.2}$ and $\mathrm{G}-\mathrm{GO}_{0.25}$ MFCs were $79.69 \pm 0.65 \%, 80.35 \pm 0.48 \%, 82.78 \pm 0.45 \%$ and $79.10 \pm 0.74 \%$, respectively. The CEs of the corresponding MFCs were $30.24 \pm 0.46 \%, 30.78 \pm 0.40 \%, 33.76 \pm 0.43 \%$ and $30.10 \pm 0.46 \%$, respectively. Similarly, the MFC with the $\mathrm{G}-\mathrm{GO}_{0.2}$ anode exhibited slightly higher substrates removal and efficacious utilization than other MFCs.

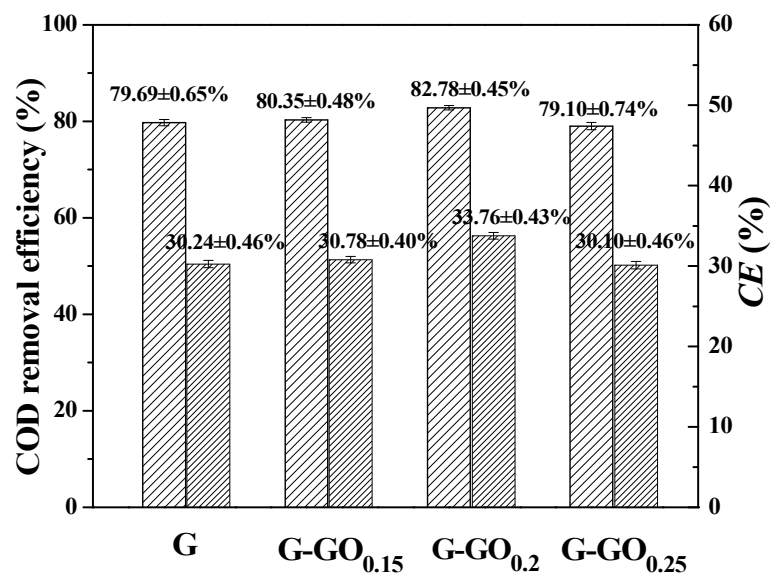

Figure 4. Chemical oxygen demand (COD) removal efficiency and CE of MFCs with G and GO anodes. 


\subsection{Electrochemical Characterization of $G$ and $G O$ Anodes}

Cyclic voltammograms (CVs) and electrochemical impedance spectra (EIS) tests were conducted to evaluate the electrochemical activity of the G and G-GO anodes before and after running. As shown in Figure 5a, no redox peak appeared on the CV curves, which indicated that there was no electrochemically active substance on the anodes. With the increase of GO, the current density of the corresponding anodes gradually decreased, suggesting that the doping of GO slightly decreased the double layer capacitance of the anodes [24]. According to Figure $5 \mathrm{~b}$, the ohmic resistances $\left(R_{\mathrm{ohm}}\right)$ of the anodes were almost the same which was probably because graphene had excellent conductivity and adding small amount of GO has not changed the overall conductivity of the anodes. However, the charge transfer resistance $\left(R_{\mathrm{ct}}\right)$ of the anodes gradually increased with the increase of the GO, probably due to the variation of the double layer capacitance. This phenomenon also appeared in the previous reported $\mathrm{MnO}_{2}$ modified anodes [25,26].
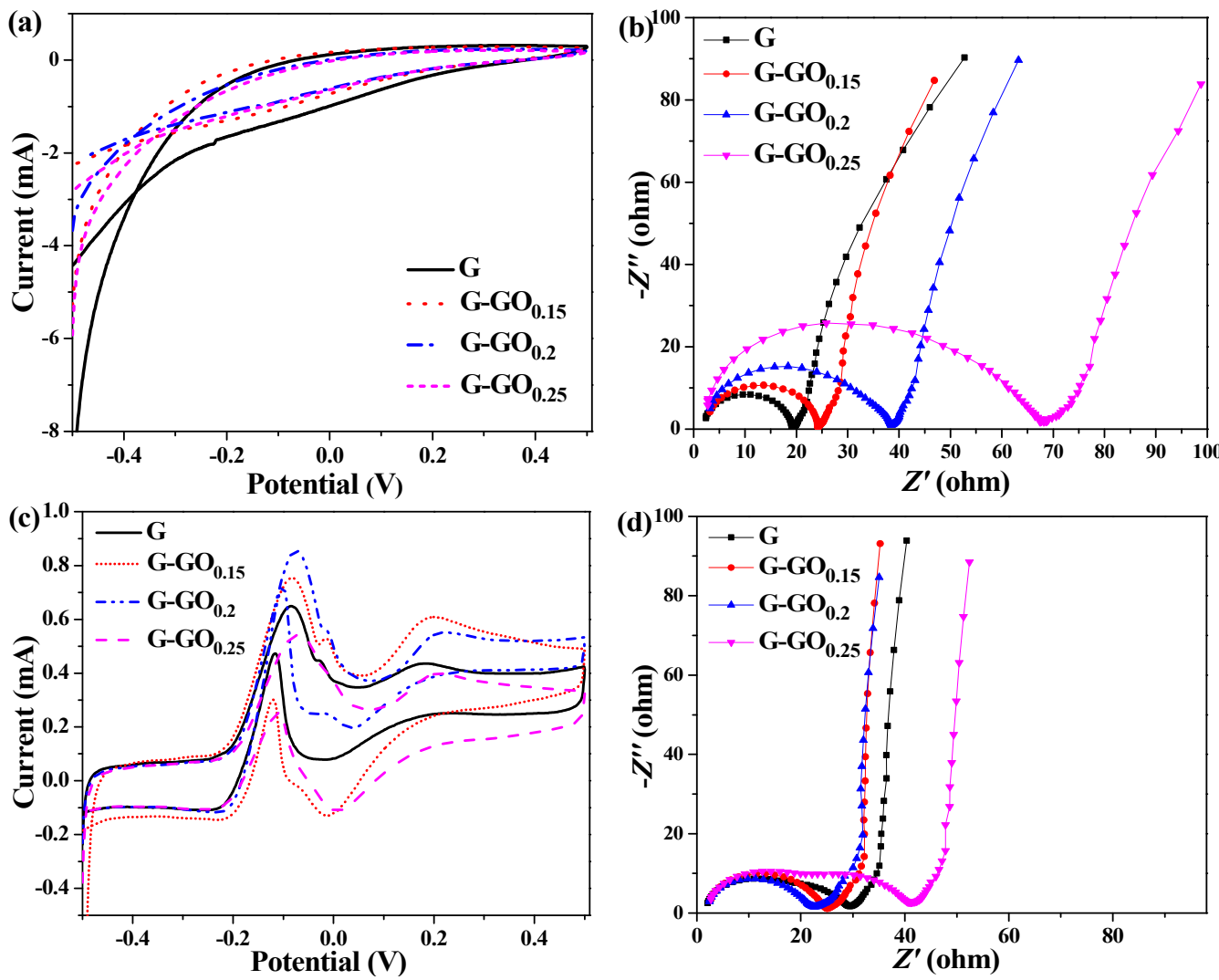

Figure 5. Cyclic voltammograms (CVs) and Nyquist plots of G and GO anodes before (a,b) and after (c,d) running.

As can be seen from Figure 5c, after running, three couples of redox peaks appeared on the CV curves of the MFCs, which was consistent with the trait of the G. sulfurreducens biofilm $[27,28]$. Within this, the first peak in the forward scan near $-0.08 \mathrm{~V}$ and the second peak in the reverse scan around $-0.22 \mathrm{~V}$ might be due to the bio-electrocatalytic redox reaction of acetate [29]. The oxidation peak currents of the $\mathrm{G}-\mathrm{GO}_{0.15}$ and the $\mathrm{G}-\mathrm{GO}_{0.2}$ anode were obviously higher than that of the $\mathrm{G}$ and the $\mathrm{G}-\mathrm{GO}_{0.25}$ anode, indicating their relatively higher anodic biocatalysis. The other couple of peaks were probably due to the existence of electrocatalytic active substances on the outer membranes of the exoelectrogens (like the cytochrome, $O m c B, O m c E$ or $O m c S$ ) [30]. Figure 5d showed the Nyquist plots of different anodes after running. Compared with the Nyquist plots in Figure $5 b$, the change of the $R_{\mathrm{ohm}}$ for the anodes was negligible while the $R_{\mathrm{ct}}$ of the anodes obviously decreased after running, 
which revealed the forming of electrochemical active biofilms. The $R_{\mathrm{ct}}$ of the $\mathrm{G}-\mathrm{GO}_{0.15}$ and G-GO 0.2 were $23.07 \Omega$ and $20.56 \Omega$, respectively, which were much smaller than that of the $G$ anode $(28.14 \Omega)$ indicating that the extracellular electron transfer (EET) in the biofilms of G-GO anodes were greatly enhanced [31,32]. However, the $R_{\text {ct }}$ of the G-GO $\mathrm{G}_{0.25}$ anode increased to $39.02 \Omega$, suggesting that excess GO in the modification layer adversely affected the EET.

\subsection{Anode Biomass}

In MFC, substrates are oxidized by the electrochemically active microorganisms growing on the surface of the anode to generate electrons, and then these electrons transfer into the external circuit and finally arrive at the cathode to be consumed by electron accepters to complete the electricity generation circulation [33]. Therefore, the more electrochemically active microorganisms attached on the anode surface, the more electrons generated and the higher $P_{\max }$ of the MFC. As shown in Table 1, the amount of microbial biomasses on the anode surfaces of the MFCs were characterized by the phospholipid concentrations [21]. The phospholipid concentration of the biofilm on the G anode was $6.68 \pm 0.57 \mu \mathrm{g} \cdot \mathrm{cm}^{-2}$. The $\mathrm{G}-\mathrm{GO}_{0.15}$ and $\mathrm{G}-\mathrm{GO}_{0.2}$ anodes showed obvious higher phospholipid concentrations. As the GO doped ratio increased from $0.15 \mathrm{mg} \cdot \mathrm{mg}^{-1}$ to $0.2 \mathrm{mg} \cdot \mathrm{mg}^{-1}$, the phospholipid concentration on the corresponding anodes ascended from $6.86 \pm 0.56 \mu \mathrm{g} \cdot \mathrm{cm}^{-2}$ to $7.07 \pm 0.56 \mu \mathrm{g} \cdot \mathrm{cm}^{-2}$, respectively. Hence, it can be seen that the doped GO enhanced the hydrophilicity of the anodes and evidently promoted the microbial attachment and growth on the anodes. However, excess GO doped into the modified layer obviously decreased the double layer capacitance of the anode, hindered the EET between the biofilm and the anode, and finally limited the reproduction of the bacteria on the anode surface. Therefore, the phospholipid concentration of the biofilm on the G-GO $\mathrm{G}_{0.25}$ anode was lower than that of the $\mathrm{G}$ anode.

Table 1. The phospholipid concentrations of G and G-GO anodes.

\begin{tabular}{ccccc}
\hline Anodes & G & G-GO & G-15 $_{0.2}$ & G-GO $_{0.25}$ \\
\hline Phospholipid concentration $\left(\mu \mathrm{g} \cdot \mathrm{cm}^{-2}\right)$ & $6.68 \pm 0.57$ & $6.86 \pm 0.56$ & $7.07 \pm 0.56$ & $6.11 \pm 0.57$ \\
\hline
\end{tabular}

\section{Conclusions}

The hydrophilicity of the G anodes was elevated by doping small amounts of GO. As the GO doped ratio increased from $0.15 \mathrm{mg} \cdot \mathrm{mg}^{-1}$ to $0.2 \mathrm{mg} \cdot \mathrm{mg}^{-1}$ and $0.25 \mathrm{mg} \cdot \mathrm{mg}^{-1}$, the static water contact angle $\left(\theta_{c}\right)$ of the G-GO anodes decreased from $74.2 \pm 0.52^{\circ}$ to $64.6 \pm 2.75^{\circ}$ and $41.7 \pm 3.69^{\circ}$, respectively. Under the combined influence of the hydrophilicity and the double layer capacitance, the $\mathrm{G}^{-} \mathrm{GO}_{0.2}$ anode with medium graphene doping ratio achieved the greatest performance. The $P_{\max }$ of the MFC with $\mathrm{G}-\mathrm{GO}_{0.2}$ anode was $1100.18 \mathrm{~mW} \cdot \mathrm{m}^{-2}$ which was 1.51 times higher than that of the MFC with the $\mathrm{G}$ anode. In conclusion, doping a moderate amount of $\mathrm{GO}$ was feasible to further improve the performance of the $G$ anodes and boost the output power of MFCs.

Acknowledgments: This work is supported by the grants from the National Natural Science Foundation of China (No. 21206058), the Major Science and Technology Program for Water Pollution Control and Treatment (No. 2012ZX07101-013-04), the Fundamental Research Funds for the Central Universities (No. JUSRP51512) and the Postdoctoral Research Funding Plan of Jiangsu Province (No. 1302165C).

Author Contributions: Na Yang and Yueping Ren designed and performed the experiments; Xiufen Li and Xinhua Wang contributed materials and analysis tools; Na Yang and Yueping Ren analyzed the data and wrote the paper.

Conflicts of Interest: The authors declare no conflict of interest. 


\section{References}

1. Logan, B.E.; Regan, J.M. Microbial fuel cells-challenges and applications. Environ. Sci. Technol. 2006, 40, 5172-5180. [CrossRef] [PubMed]

2. Li, W.W.; Yu, H.Q.; He, Z. Towards sustainable wastewater treatment by using microbial fuel cells-centered technologies. Energy Environ. Sci. 2014, 7, 911-924. [CrossRef]

3. Bullen, R.A.; Arnot, T.C.; Lakeman, J.B.; Walsh, F.C. Biofuel cells and their development. Biosens. Bioelectron. 2006, 21, 2015-2045. [CrossRef] [PubMed]

4. Kannan, M.V.; Kumar, G.G. Current status, key challenges and its solutions in the design and development of graphene based ORR catalysts for the microbial fuel cell applications. Biosens. Bioelectron. 2016, 77, 1208-1220. [CrossRef] [PubMed]

5. Xue, L.; Yang, N.; Ren, Y.; Li, X.; Shi, Y.; Hua, Z.; Wang, X. Effect of binder-free graphenecetyltrimethylammonium bromide anode on the performance of microbial fuel cells. J. Chem. Technol. Biot. 2016. [CrossRef]

6. Commault, A.S.; Barrière, F.; Lapinsonnière, L.; Lear, G.; Bouvier, S.; Weld, R.J. Influence of inoculum and anode surface properties on the selection of Geobacter-dominated biofilms. Bioresour. Technol. 2015, 195, 265-272. [CrossRef] [PubMed]

7. Guo, K.; Freguia, S.; Dennis, P.G.; Chen, X.; Donose, B.C.; Keller, J.; Gooding, J.J.; Rabaey, K. Effects of surface charge and hydrophobicity on anodic biofilm formation, community composition, and current generation in bioelectrochemical systems. Environ. Sci. Technol. 2013, 47, 7563-7570. [CrossRef] [PubMed]

8. Zhang, Y.Z.; Mo, G.Q.; Li, X.W.; Zhang, W.D.; Zhang, J.Q.; Ye, J.S.; Huang, X.D.; Yu, C.Z. A graphene modified anode to improve the performance of microbial fuel cells. J. Power Sources 2011, 196, 5402-5407. [CrossRef]

9. Chou, H.T.; Lee, H.J.; Lee, C.Y.; Tai, N.H.; Chang, H.Y. Highly durable anodes of microbial fuel cells using a reduced graphene oxide/carbon nanotube-coated scaffold. Bioresour. Technol. 2014, 169, 532-536. [CrossRef] [PubMed]

10. Zhu, Y.W.; Murali, S.; Cai, W.W.; Li, X.S.; Suk, J.W.; Potts, J.R.; Ruoff, R.S. Graphene and graphene oxide: Synthesis, properties, and applications. Adv. Mater. 2010, 22, 3906-3924. [CrossRef] [PubMed]

11. Martin, R.-L.; Christoph, G.S. A simple and mild chemical oxidation route to high-purity nano-graphene oxide. Carbon 2016, 106, 56-63.

12. Marcano, D.C.; Kosynkin, D.V.; Berlin, J.M.; Sinitskii, A.; Sun, Z.Z.; Slesarev, A.; Alemany, L.B.; Lu, W.; Tour, J.M. Improved synthesis of graphene oxide. ACS Nano 2010, 4, 4806-4814. [CrossRef] [PubMed]

13. Wu, T.F.; Zhou, B.M.; Zhu, T.; Shi, J.; Xu, Z.W.; Hu, C.S.; Wang, J.J. Facile and low-cost approach towards a PVDF ultrafiltration membrane with enhanced hydrophilicity and antifouling performance via graphene oxide/water-bath coagulation. RSC Adv. 2015, 5, 7880-7889. [CrossRef]

14. Ganesh, B.M.; Isloor, A.M.; Ismail, A.F. Enhanced hydrophilicity and salt rejection study of graphene oxide-polysulfone mixed matrix membrane. Desalination 2013, 313, 199-207. [CrossRef]

15. Krishnamoorthy, K.; Navaneethaiyer, U.; Mohan, R.; Lee, J.; Kim, S.-J. Graphene oxide nanostructures modified multifunctional cotton fabrics. Appl. Nanosci. 2012, 2, 119-126. [CrossRef]

16. Dong, H.; Yu, H.B.; Wang, X.; Zhou, Q.X.; Feng, J.L. A novel structure of scalable air-cathode without Nafion and Pt by rolling activated carbon and PTFE as catalyst layer in microbial fuel cells. Water Res. 2012, 46, 5777-5787. [CrossRef] [PubMed]

17. Liu, H.; Logan, B.E. Electricity generation using an air-cathode single chamber microbial fuel cell in the presence and absence of a proton exchange membrane. Environ. Sci. Technol. 2004, 38, 4040-4046. [CrossRef] [PubMed]

18. Zhang, F.; Cheng, S.A.; Pant, D.; Van Bogaert, G.; Logan, B.E. Power generation using an activated carbon and metal mesh cathode in a microbial fuel cell. Electrochem. Commun. 2009, 11, 2177-2179. [CrossRef]

19. Kang, Y.L.; Ibrahim, S.; Pichiah, S. Synergetic effect of conductive polymer poly (3,4-ethylenedioxythiophene) with different structural configuration of anode for microbial fuel cell application. Bioresour. Technol. 2015, 189, 364-369. [CrossRef] [PubMed]

20. Hou, J.X.; Liu, Z.L.; Zhang, P.Y. A new method for fabrication of graphene/polyaniline nanocomplex modified microbial fuel cell anodes. J. Power Sources 2013, 224, 139-144. [CrossRef] 
21. Wei, J.C.; Liang, P.; Cao, X.X.; Huang, X. A new insight into potential regulation on growth and power generation of Geobacter sulfurreducens in microbial fuel cells. Environ. Sci. Technol. 2010, 44, 3187-3191. [CrossRef] [PubMed]

22. Yu, H.K.; Ziegler, C.; Oszcipok, M.; Zobel, M.; Hebling, C. Hydrophilicity and hydrophobicity study of catalyst layers in proton exchange membrane fuel cells. Electrochim. Acta 2006, 51, 1199-1207. [CrossRef]

23. Chen, Z.H.; Li, K.X.; Zhang, P.; Pu, L.T.; Zhang, X.; Fu, Z. The performance of activated carbon treated with $\mathrm{H}_{3} \mathrm{PO}_{4}$ at $80{ }^{\circ} \mathrm{C}$ in the air-cathode microbial fuel cell. Chem. Eng. J. 2015, 259, 820-826. [CrossRef]

24. Zhang, C.Y.; Liang, P.; Yang, X.F.; Jiang, Y.; Bian, Y.H.; Chen, C.M.; Zhang, X.Y.; Huang, X. Binder-free graphene and manganese oxide coated carbon felt anode for high-performance microbial fuel cell. Biosens. Bioelectron. 2016, 81, 32-38. [CrossRef] [PubMed]

25. Yuan, H.R.; Deng, L.F.; Chen, Y.; Yuan, Y. $\mathrm{MnO}_{2} /$ Polypyrrole $/ \mathrm{MnO}_{2}$ multi-walled-nanotube-modified anode for high-performance microbial fuel cells. Electrochim. Acta 2016, 196, 280-285. [CrossRef]

26. Li, L.; Hu, Z.A.; An, N.; Yang, Y.Y.; Li, Z.M.; Wu, H.Y. Facile synthesis of $\mathrm{MnO}_{2} / \mathrm{CNTs}$ composite for supercapacitor electrodes with long cycle stability. J. Phys. Chem. 2014, 118, 22865-22872. [CrossRef]

27. Katuri, K.P.; Kavanagh, P.; Rengaraj, S.; Leech, D. Geobacter sulfurreducens biofilms developed under different growth conditions on glassy carbon electrodes: Insights using cyclic voltammetry. Chem. Commun. 2010, 46, 4758-4760. [CrossRef] [PubMed]

28. Marsili, E.; Rollefson, J.B.; Baron, D.B.; Hozalski, R.M.; Bond, D.R. Microbial biofilm voltammetry: Direct electrochemical characterization of catalytic electrode-attached biofilms. Appl. Environ. Microbiol. 2008, 74, 7329-7337. [CrossRef] [PubMed]

29. Chae, K.J.; Choi, M.J.; Lee, J.W.; Kim, K.Y.; Kim, I.S. Effect of different substrates on the performance, bacterial diversity, and bacterial viability in microbial fuel cells. Bioresour. Technol. 2009, 100, 3518-3525. [CrossRef] [PubMed]

30. Zhu, X.P.; Yates, M.D.; Logan, B.E. Set potential regulation reveals additional oxidation peaks of Geobacter sulfurreducens anodic biofilms. Electrochem. Commun. 2012, 22, 116-119. [CrossRef]

31. Manohar, A.K.; Bretschger, O.; Nealson, K.H.; Mansfeld, F. The polarization behavior of the anode in a microbial fuel cell. Electrochim. Acta 2008, 53, 3508-3513. [CrossRef]

32. Manohar, A.K.; Mansfeld, F. The internal resistance of a microbial fuel cell and its dependence on cell design and operating conditions. Electrochim. Acta 2009, 54, 1664-1670. [CrossRef]

33. Sun, M.; Zhai, L.F.; Li, W.W.; Yu, H.Q. Harvest and utilization of chemical energy in wastes by microbial fuel cells. Chem. Soc. Rev. 2016, 45, 2847-2870. [CrossRef] [PubMed]

(C) 2016 by the authors; licensee MDPI, Basel, Switzerland. This article is an open access article distributed under the terms and conditions of the Creative Commons Attribution (CC-BY) license (http://creativecommons.org/licenses/by/4.0/). 